\title{
The indebtedness of
}

\section{households up until the} economic adjustment programme for Portugal: an empirical assessment

JOSÉ RICARDO BORGES ALVES, Ph.D.*

RITA MARIA HENRIQUES PEREIRA, MsC.*

\section{Article**}

JEL: C24; E44; E51; H31

https://doi.org/10.3326/pse.44.4.5*

\footnotetext{
* The authors would like to thank the two independent reviewers for their most useful suggestions and comments. The authors acknowledge financial Support from FCT - Fundação para a Ciência e Tecnologia (Portugal), national funding through research grant UIDB/05069/2020.

${ }^{* *}$ Received: December 2, 2019

Accepted: July 17, 2020
}

José Ricardo Borges ALVES

UECE/REM- ISEG, Universidade de Lisboa, Rua Miguel Lupi, 20 - 1249-078 Lisboa, Portugal

e-mail: jalves@iseg.ulisboa.pt

ORCiD: 0000-0002-9979-7544

Rita Maria Henriques PEREIRA

ISEG, Universidade de Lisboa, Rua do Quelhas, 6 - 1200-781 Lisboa, Portugal

e-mail: ritamhp@gmail.com 


\section{Abstract}

Ever since the 2008 financial crisis, authorities have been particularly aware of the necessity to be provided with early warning indicators regarding financial stability. Indeed, the Basel Committee on Banking Supervision suggests conducting an analysis of the difference between the private sector credit-to-GDP ratio and its own long-term trend, even though this ratio has been criticised for its poor suitability to countries that have experienced a rapid build-up of credit. For the past two decades, Portugal has witnessed a dramatic increase in the indebtedness of households and the objective of this paper is precisely to examine the relationship between private credit and GDP from 1961 to 2011. Based on the methodology employed in Kelly, McQuinn and Stuart (2011) for the Portuguese case, our main conclusions are the non-suitability of the Basel Committee on Banking Supervision approach for Portugal and the rupture of the link between deposits and credit from 1992 onwards.

Keywords: indebtedness of households, early warning indicators, credit, Portugal

\section{INTRODUCTION}

The indebtedness of Portuguese households has not been receiving the amount of attention it deserves. Since the 1990s, the levels of indebtedness have been increasing dramatically, the main reason being that household demand for home purchase has fuelled a rapid growth in credit. The indebtedness of Portuguese households is definitely a topic worth looking closely at due to its peculiar evolution. Portugal is a small and open economy and its households have worrisome levels of indebtedness. According to Castro (2006), the indebtedness of households in Portugal in 1990 was 20 per cent of disposable income, in 1995 it was 40 per cent, and by 2004 it was already 118 per cent. Furthermore, and as illustrated in Figure 1, up until 2011 this trend has shown no signs of slowing down. In fact, this pattern is not exclusive to Portugal, as demonstrated in Kelly, McQuinn and Stuart (2011). In particular, Ireland, the United Kingdom, Spain, and the Netherlands have all indeed experienced the same trajectory of household indebtedness as Portugal. In order to understand the possible reasons for this behaviour it is worth analysing the country's evolution over the past few decades. After the Second World War, Portugal enjoyed the so-called "golden years" of global economic growth that began in 1950. Furthermore, Portugal's integration with several economic organisations - such as the Organization for Economic Co-operation and Development (OECD), the European Free Trade Association (EFTA), the General Agreement on Tariffs and Trade (GATT), and the European Economic Community (ECC), led to a large integration of the country's economy. However, in the 1970s the situation changed: there were two oil shocks (1973 and 1979) followed by the collapse of the Bretton Woods System, and, most importantly, the April $25^{\text {th }}$ Revolution - which ended the 41 years of dictatorial regime in Portugal. 


\section{Figure 1}

Domestic credit to the private sector in Portugal as \% of GDP, 1961-2011

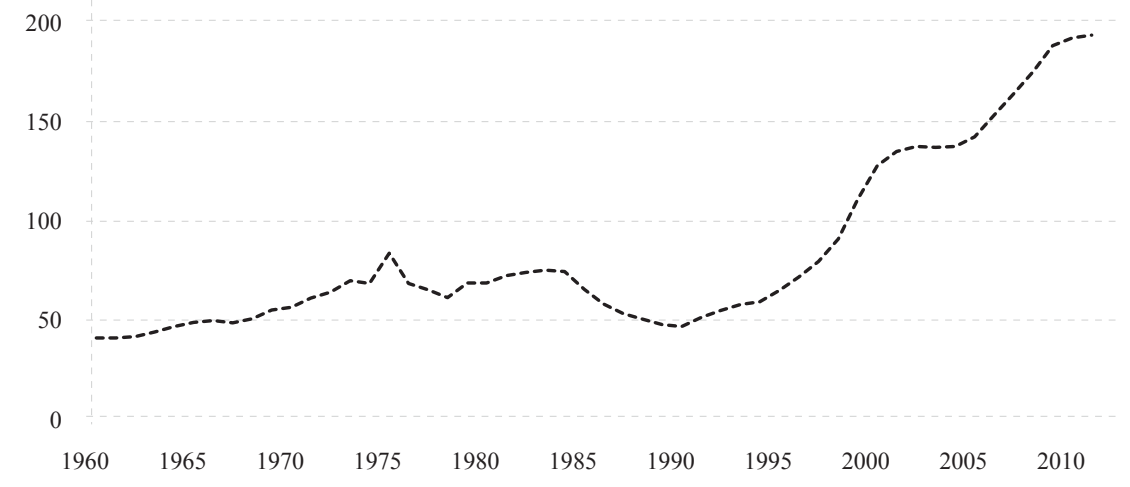

Source: World Bank (2013).

In May 1978, Portugal had no choice but to ask for the International Monetary Fund (IMF) for help to stabilise the troubling macroeconomic environment being felt at the time. With the onset of the second oil crisis in 1979, which was obviously not helpful for the already-fragile situation, the problems Portugal was facing at the time became even worse. After years of struggle, in September 1983 the IMF was called upon for the second time to aid the country overcome its serious macroeconomic imbalances. In 1986 Portugal joined the ECC - now the European Union (EU) - and not only was this an extremely important economic and political milestone, but it was also a crucial point in explaining in part the evolution of the indebtedness of Portuguese households. Portugal embraced the European project and from then onwards started to enjoy the benefits that arise from being tied to the major European economies: economic development, lower inflation, lower interest rates, and higher macroeconomic stability. However, one should take into account that after the April $25^{\text {th }}$ Revolution Portugal was, literally, decades behind some of its European colleagues.

It was also in 1986 that the Portuguese Government started a programme called Crédito Bonificado, which was intended to help low-income households by providing interest rate reductions to those who had purchased, or wanted to purchase a house through a mortgage loan. This programme helped many households with modest incomes and also many vulnerable families who were returning from Portugal's former colonies to be able to afford decent and affordable housing. According to the Direcção Geral do Tesouro e Finanças (the Portuguese's DirectorateGeneral for the Treasury and Finance), from 1990 to 1998 more housing contracts were signed under the Crédito Bonificado programme than under the general regime ${ }^{1}$. From 1999 to 2002, the year that the programme ended, there was a reversal of the situation. Furthermore, in 1999 the DCPS-to-GDP ratio was already

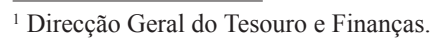


at a rather high level and it kept increasing at an astonishing pace up until 2011, as depicted in Figure 1.

In addition, when the Maastricht Treaty was signed, the EU was created and the first steps for the creation of a single European currency - the euro - were taken, along with criteria which countries needed to achieve in order to join the euro. In 1999, the European Currency Unit (ECU) was introduced, and later in 2002 euro notes and coins were officially introduced. Consequently, markets and investors became myopic with regards to each country's risk and interest rates started to decline, as Figure 2 depicts for Portugal.

The Portuguese banking sector took advantage of these years of low interest rates and started to obtain financing in international financial markets in order to keep up with and stimulate the demand of households for their own homes, since domestic resources were inadequate to properly sustain the credit granted. The interest rate decreased as a result of liberalisation and the increase of bank competition, which extended the access to credit to a broader group of households than in previous decades (Farinha, 2008). Portuguese families experienced perspectives for economic growth and even those with a modest income were able to invest in homes. Another consideration regarding the housing sector that must be seriously taken into account concerns the private renting sector. According to the Associação Lisbonense de Proprietários (2011), the first legislative action towards a rent freeze was in November 1920 and later on the eve of the April $25^{\text {th }}$ Revolution in 1974, when some rents in Lisbon and Porto had not been updated since the end of the First World War. Even though some measures had been taken to change the situation, the private renting sector continued to be subject to restrictions and due to a long rent freeze, the housing supply was limited. Landlords simply did not find it attractive to rent their properties, and additionally, rents which had been updated were sometimes higher than the monthly mortgage instalments that households would have to pay if they purchased their own homes.

In a time when interest rates were decreasing and banks were willing to provide generous mortgage loans, many families entered into debt and purchased their own home, with some households even investing in a second home. This was the primary cause of the indebtedness of Portuguese households. In view of the restrictions affecting the private renting sector's supply and the low interest rates, some argue that households were forced to get into debt in order to obtain proper housing at a reasonable price. Portugal became a nation of homeowners. Furthermore, according to the Associação Lisbonense de Proprietários (2011), by 2001, 75\% of Portuguese houses were actually occupied by their owner, compared to $57 \%$ in 1987 . Conversely, the number of tenants decreased from $39 \%$ in 1981 to $21 \%$ in 2001 .

Fast-forwarding to 2010, the economic environment becomes drastically different. With the financial crisis of 2008, the formerly short-sighted investors became extremely aware that the single currency was not going to mitigate each country's 
risk. The interest rate convergence that once existed simply disappeared. As shown in Figure 2, the long-term interest rate had experienced an exponential increase from 2010 with the beginning of the sovereign debt crisis, up until approximately 2011. Being unable to deal with the interest rate increase and the unstable economic environment, Portugal had to ask the IMF for help in May 2011, for the third time, which explains the decline in the interest rate - at least until 2012. That being said, the years 2008 to 2011 were difficult for those Portuguese families which are indebted, and it is unfortunately common to hear about families that could simply can no longer pay their mortgage. It is for this reason that the Portuguese case should not simply be ignored.

\section{Figure 2}

Long-term interest rate for convergence purposes for Portugal, 1993-2012

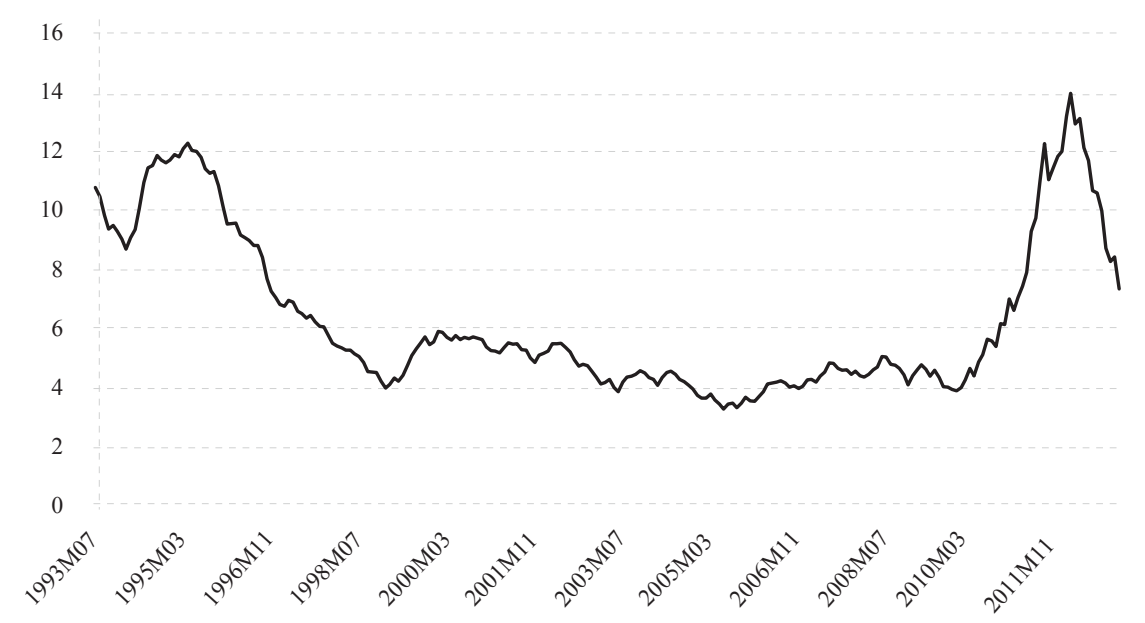

Source: ECB (2018).

Indebted households are more vulnerable to unanticipated shocks - such as unemployment, a decrease in disposable income, or a hike in interest rate - which increases the probability of default and, consequently threatens the country's financial stability. Therefore, the possession of indicators capable of helping authorities flag periods of excessive credit (which usually results in financial instability) became a major concern, particularly since the 2008 financial crisis.

In fact, the Basel Committee on Banking Supervision (BCBS) suggests the use of the Hodrick-Prescott (HP) filter to determine the Private Sector Credit-to-GDP Gap i.e., the difference between the credit-to-GDP ratio and its own long-term trend. It recommends this filter as a common starting point for authorities to determine whether there is excessive credit growth. These so-called "early warning indicators" should be seriously considered, although authorities still have to exercise judgement when making decisions. The BCBS approach has been criticised, 
because it has not been considered applicable to countries that had a rapid buildup of credit.

Our article evaluates the relationship between economic growth and credit to the private sector for the Portuguese case, following the methodology applied in Kelly, McQuinn and Stuart (2011). We opt for adopting the same methodology as those authors employed for the Irish case, as Ireland is the same type of small open European and eurozone economy as that of Portugal and it has experienced similar patterns of rapid accumulation of private sector credit. Therefore, and given the similarities of both countries' economies, we decided to adopt the same methodology to analyse the relationship between the domestic credit of private sector and real GDP. Our results point to the non-suitability of the BCBS approach for Portugal and the break of the deposits-credit link from 1992 onwards.

The paper is organised as follows: section 2 reviews the literature, the trajectory of Portuguese household indebtedness as well as the importance of "early warning indicators" and the criticisms of the BCBS approach; section 3 presents our methodology and, lastly, section 4 discusses our results and summarizes the article's conclusions.

\section{LITERATURE REVIEW}

Financial stability has been at the heart of the authorities' concerns since 2008, when the financial crisis struck the financial system and the most developed economies (see, for instance, Borio, McCauley and McGuire, 2011; Bruno and Shin, 2015). The crisis highlighted the need for stable financial markets and a sound banking sector, as well as the need for a high-quality buffer to aid banks in more unstable times. As Shin (2013:3) states, "finding a set of early warning indicators that can signal the vulnerability to financial turmoil has emerged as a policy goal of paramount importance in the aftermath of the global financial crisis."

To help national authorities know how to intervene when financial distress is a concern, the BCBS drew up procedures to guide national authorities that use the countercyclical capital buffer regime. The BCBS is composed of more than 20 countries and provides a forum that promotes cooperation regarding banking regulation and supervision worldwide, with the objective of improving and enhancing financial stability. The BCBS requires the analysis of the private sector creditto-GDP gap, as this is considered to be a good indicator of financial stability or an early warning indicator. The buffer regime aims to protect the banking sector from the credit cycle, i.e., from periods when credit experiences excessive growth, usually associated with riskier behaviours that can compromise financial stability. There is also the concern to keep the banking sector solvent, stable, and protected against possible future losses, since its weaknesses can rapidly spill over to the real economy. Banks are the link between savers and investors and are vital for companies and Governments, which, on a daily basis, depend on credit to carry out their activities (see, for instance, Drehmann and Juselius, 2014). 
To determine whether the sector is strong or not, indicators have to be used. The issue here, however, is that a choice of the variable on which to rely has to be made. Accordingly, the aggregate private sector credit-to-GDP gap was determined as a common starting point. This is the difference between the credit-toGDP ratio and its own long-term trend, and it requires using the HP-filter. Other indicators are suggested by the BCBS to complement this reference tool, such as real GDP growth, credit condition surveys, funding spreads, and CDS spreads, among other things. It is also important to be aware of the importance of the behaviour of GDP, as this is the denominator of the ratio which is used as a common reference.

However, this BCBS approach is not criticism-proof. Geršl and Seidler (2011) argue that the HP-filter approach is not the most suitable one for Central and Eastern European countries, since the rapid credit growth of these countries could simply indicate a convergence process towards the advanced economies. The authors present an estimation of these countries' equilibrium private credit levels as an alternative indicator for excessive credit growth. Shin (2013) examines the power of three classes of early warning indicators in signalling vulnerability to crises. The author concludes that market prices-based indicators are unlikely to succeed and that the most promising ones are those which use banking sector liability aggregates, as these can be used in real time. Regarding the credit-to-GDP ratio gap, doubts exist regarding its ability to be used in real time. Kelly, McQuinn and Stuart (2011) also raise doubts concerning the success of the indicator for those countries which experienced a rapid build-up of credit and focus their analysis on the Irish case. The authors suggest a Markov Switching framework to analyse the periods when the credit-to-GDP ratio was stable to examine the longterm trend during those periods. On the other hand, Giese et al. (2014) were able to show that the BCBS approach works for the UK, and that it provided sound signals of financial crises.

The dichotomy of these results could indicate that the BCBS proposal is not the best one for countries that experienced a rapid build-up of credit - such as Portugal, Ireland, and the Central and Eastern European countries - however it is suitable for more advanced economies, such as that of the UK. In fact, the BCBS points out that this indicator should only be considered as a common reference and starting point for national authorities to make decisions. The committee also advises authorities about the need for reasoning and judgment when carrying out analysis, the indicator should not be used just as a mathematic indicator for decision making.

Despite the criticism, some authors have confirmed the importance of the creditto-GDP ratio as an early-warning indicator. For instance, Jordà, Schularick and Taylor (2011) show that credit growth is a good indicator for financial instability and that the relation between credit growth and current accounts has been becoming tighter. Drehmann, Borio and Tsatsaronis (2011) show that the deviation of the credit-to-GDP ratio is a good indicator for the build-up phase - the phase when 
credit growth is considerable - although it does not send many false signals regarding the imminence of a crisis. Other indicators, such as credit growth and equity price growth, are also considered to be good indicators, even though they are not as good as the former. Regarding the release phase, Drehmann, Borio and Tsatsaronis (2011) show that market-base indicators are those that best signal the beginning of a crisis, even though their performance is by much worse than the performance of the indicators during the build-up phase. Drehmann et al. (2010) show that the difference between credit-to-GDP ratio and its long-term trend seems to be the best indicator for the build-up phase, although authorities cannot rely on this indicator entirely without exercising their judgment regarding each situation. Drehmann (2013) concludes that the gaps of bank and total credit-toGDP ratios are good early-warning indicators and that these can help in the countercyclical capital buffer regime. Furthermore, Aldasoro, Borio and Drehmann (2018) conclude that household debt provides some very useful information as an early warning indicator. In fact, these authors support the opinion that this source of debt, together with international debt data, can supply important insights regarding systemic banking crisis events.

Modern economies rely heavily on credit and it is crucial for a country to be aware of these early warning indicators. An indicator which can measure, to some extent, financial instability is a great reference point, but it is nothing more than that. National authorities should not use this indicator or any other indicator merely as a mathematical rule, and should always complement their decisions with judgment and discretion (Drehmann and Tsatsaronis, 2014).

Regarding the indebtedness of Portuguese households, this topic has not been explored very much by scholars and neither have Portuguese politicians paid the amount of attention to this structural problem for the Portuguese economy that it deserves. Therefore, the main contributions regarding this issue have been the statistics produced by the Economic Research Department of Banco de Portugal. Farinha and Noorali (2004) use the data from the 2000s Households' Wealth and Indebtedness Survey in detail to analyse aggregate indicators regarding Portuguese households' wealth and indebtedness. The authors show how house purchase credit is the main reason for the household debt. They posit that although household wealth has increased over the past two decades, the indebtedness of households has grown even more. The authors do not think that the more vulnerable households (indebted young families) represent any risk to financial stability, even though they acknowledge that these highly-indebted households would be extremely affected if they had to face unemployment, income reduction, or an interest rate increase. In addition, Castro (2006) elaborates a model for cases in which consumers face liquidity constraints in order to study the sensitivity of Portuguese household consumption to disposable income. His model shows a reduction in liquidity constraints in the 1990 decade due to the decrease in interest rates and the increase of financial liberalisation. Consumption increases at the end of the same decade and the beginning of the 2000s with a respective increase of 
the indebtedness of households as a percentage of disposable income. Furthermore, Farinha (2008) uses the data from the 2006/2007s Households' Wealth and Indebtedness Survey to analyse the indebtedness of Portuguese households. Once again, the author concludes that the most vulnerable households are the young and low-income families, although their share of the debt market is relatively low when compared with the total and they pose little or no risk to financial stability.

Farinha and Costa (2012) carry out a microeconomic analysis of the results from the 2010s Household Finance and Consumption Survey, which concludes that the upward trend of the indebtedness of households throughout the last two decades has been interrupted as a consequence of the Economic Adjustment Programme that Portugal has been subject to since 2011. From the survey's results, the authors also conclude that the percentage of households which are unable to meet their financial obligations is low, but is likely to increase due to the country's difficult macroeconomic environment (such as unemployment and a decrease in disposable income). The same authors argue that the most vulnerable households are indebted low-income and young households. Even though young families' participation in the debt market is high, the amounts borrowed are not significant when compared to the total and their debts are underwritten by real estate. Therefore, the authors consider that in case of default, the impact on financial stability would be mitigated. Lastly, Costa (2012) also uses the 2010s Household Finance and Consumption Survey to determine the probability of default by taking into account the households' economic and socio-demographic features. Similar to Costa and Farinha (2012), Costa (2012) concluded that low-income households are those with a higher probability of default. His study shows that households that have defaulted did so due to unexpected shocks to their financial situation, such as unemployment, and such default would not have happened if it were not for these unanticipated shocks. The author goes on to explain that this situation shows how households were rational when taking credit decisions i.e., if no shocks had occurred, then the indebted families would have continued to be able to meet their financial commitments.

\section{EMPIRICAL ANALYSIS}

As reflected earlier, and given the similarities between the historical dynamics of indebtedness among households in Ireland and Portugal, despite the afore-mentioned features regarding economic structure, our empirical analysis follows that employed in Kelly, McQuinn and Stuart (2011). By observing the evolution of real Portuguese GDP and the ratio of Domestic Credit-to-Private Sector (DCPS) over GDP growth rates, we are able to state that neither rate exhibits a greatly correlated behaviour. Nevertheless, from 1961 to around 1973, the rates seem to be correlated (meaning there is growth in both GDP and DCPS). From 1973 to around 1989, the growth rates display a different behaviour. Due to the April 25th Revolution, the two IMF programmes that Portugal went through, and also the country's entrance to the EEC, DCPS growth is lower than GDP growth in certain years. However, from 1990 onwards, the growth rate of DCPS is substantially 
higher than GDP growth (except for 2003 and 2011), due to the decrease of interest rates that started during the 1990s and led to an increase in credit, particularly to meet the demand of households to own their own home (these dynamics can be seen in Figure 3).

\section{Figure 3}

Annual Portuguese GDP and DCPS growth rates, 1961-2011

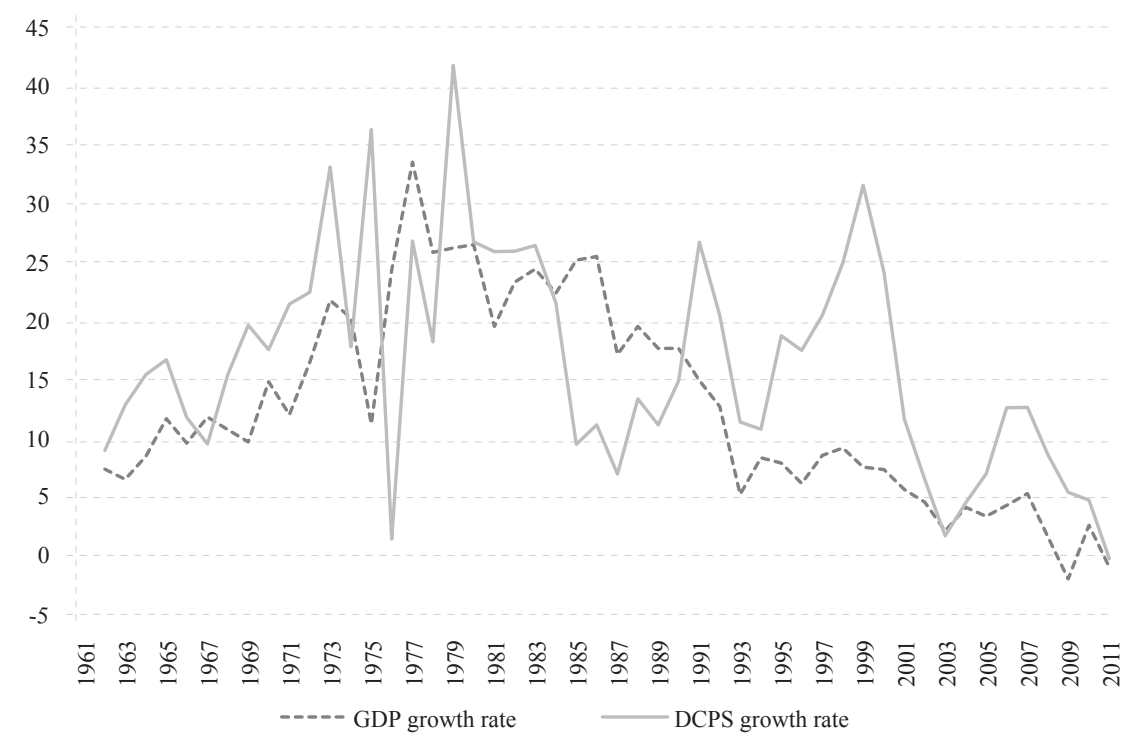

Source: World Bank (2013).

\subsection{METHODOLOGY AND DATA}

Regarding the methodology employed in this paper, we first resort to a two-state Markov Switching model to perform a structural break analysis of the DCPS-toGDP ratio. This is a widely used model and one of its advantages is that it enables the observation of multiple states in a relationship. The model takes the following form,

$$
\left(\frac{D C P S}{G D P}\right)_{t}= \begin{cases}\alpha_{1} & s(t)=1 \\ \alpha_{2} & s(t)=2\end{cases}
$$

where $s(t)$ is the state the economy is in at time t. A Markov chain determines $s(t)$ which depends on a transition matrix and can be interpreted as one being a stable state, and another being an unstable state.

After making the structural break analysis, we employ the Granger Causality Test in order to obtain information regarding the ability of each variable to predict the other. This test covers the entire period and the computed sub-periods which resulted from the structural break analysis. Next long-run regressions are carried out to understand the relationship between DCPS and GDP - not only throughout the entire period, but also during the sub-periods detected. In the interest of 
robustness, two long-run estimators were used: OLS (Ordinary Least Squares) and DOLS (Dynamic Ordinary Least Squares).

The first method estimates parameters by minimising the sum of squared residuals and it takes the following forms, depending on which variable is the independent one,

$$
\begin{aligned}
& G D P_{t}=\beta_{0}+\beta_{1} D C P S_{t}+\varepsilon_{t} \\
& D C P S_{t}=\beta_{0}+\beta_{1} G D P_{t}+\varepsilon_{t}
\end{aligned}
$$

where $\beta_{0}$ is the constant term, $\beta_{1}$ measures the effect of the independent variable on the dependent variable, and $\varepsilon$ is the error term.

The second method is the one conceived by Stock and Watson (1993). The purpose of DOLS is to determine the long-run relationship between the variables. This method not only adds lags and leads of the differenced regressors to address autocorrelation problems, but it also allows for potential endogeneity between the variables. This method is also used in models regarding credit and households. Hansen and Sulla (2013) use DOLS to determine the long-run relationship between variables in a model that aims to clarify whether credit growth in LatinAmerica is excessive and is leading to overheating in the economy leading to a housing boom, or not. Rubaszek and Serwa (2014) use DOLS in the interest of robustness to estimate the long-run relationship between the model's explanatory variables to study the credit behaviour of households over time. Depending on the dependent variable, the DOLS regressions take the following form,

$$
\begin{gathered}
G D P=\beta_{0}+\beta_{1} D C P S+\sum_{j=-k}^{k} \theta_{1, j} \Delta D C P S_{1, j}+\varepsilon \\
D C P S=\beta_{0}+\beta_{1} G D P+\sum_{j=-k}^{k} \theta_{1, j} \Delta G D P_{1, j}+\varepsilon
\end{gathered}
$$

where $\beta_{0}$ is the constant term, $\beta_{1}$ measures the effect of the independent variable on the dependent variable, $\varepsilon$ is the error term, and $\theta_{1, j}$ measures the effect of the independent variable in first differences on the dependent variable. $\triangle D C P S$ and $\triangle G D P$ are, respectively, the growth rate of DCPS and GDP. It is assumed that $\varepsilon$ follows an $\mathrm{AR}(2)$ process and that the number of leads of lags, $k$, is equal to 2. Lastly, all data is retrieved from the World Bank's World Development Indicators database, covering the period from 1961 to 2011, totalizing each variable (GDP and DCPS) 51 observations ${ }^{2}$.

\footnotetext{
${ }^{2}$ The series employed in this study for DCPS and GDP variables are the Domestic credit to private sector (\% of GDP) - Indicator code: FS.AST.PRVT.GD.ZS - and GDP (constant LCU) - Indicator code: NY.GDP. MKTP.KN -, respectively.
} 


\subsection{MARKOV SWITCHING MODEL}

Before carrying out the analysis of the reasons that could have triggered the switches, there is a need to explain both states presented in the model. State 1 is considered to be the unstable state, since it occurs during the years when the DCPS-to-GDP ratio has quick oscillations and an erratic behaviour. State 2 is considered to be the stable state and it mainly occurs during the 1961-1975 and 1992-2011 sub-periods, when the ratio has a stable behaviour in the sense that it grows continuously throughout.

The first switch observed is in around 1975, which could correspond to the April $25^{\text {th }}$ Revolution. According to Lopes (1983), there was an extreme increase in the annual average of the 6-month credit interest rate, which was 7.5\% in 1974 and $9.3 \%$ in 1975 , which may have motivated the first switch. The second switch occurs in 1978, with the advent of the first IMF programme. At this time, the annual average of the 6-month credit interest rate was $10 \%$ in $1976,13.3 \%$ in 1977, and by 1978 it was already 18.8\% (Lopes, 1983). The third switch occurred around 1985, which probably corresponds to the end of the second IMF programme, which began in 1983, which, like the first IMF programme, also established quantitative limits to credit. The fourth and last switch is in around 1992, which corresponds to the Maastricht Treaty signature which ultimately led to the associated decline in interest rates and consequently an increase in indebtedness. When analysing the DCPS-to-GDP ratio, which is depicted in Figure 1, it is clear that the ratio increases drastically from 1992 to 2011, from approximately 53.3\% in 1992 to $192.1 \%$ in 2011. The results of both the Constant Markov Transition Probabilities Matrix and the two-state Markov Switching model are presented in Table 1 and in Figure 4, respectively.

\section{TABLe 1}

Constant Markov transition probabilities matrix (all periods)

\begin{tabular}{lll}
$\frac{1}{2}$ & $\frac{\mathbf{2}}{2}$ & 0.769918 \\
0.049433 & 0.230082 \\
\hline
\end{tabular}

Source: Authors'calculations. 


\section{Figure 4}

State probabilities of the DCPS-to-GDP ratio for Portugal, 1961-2011

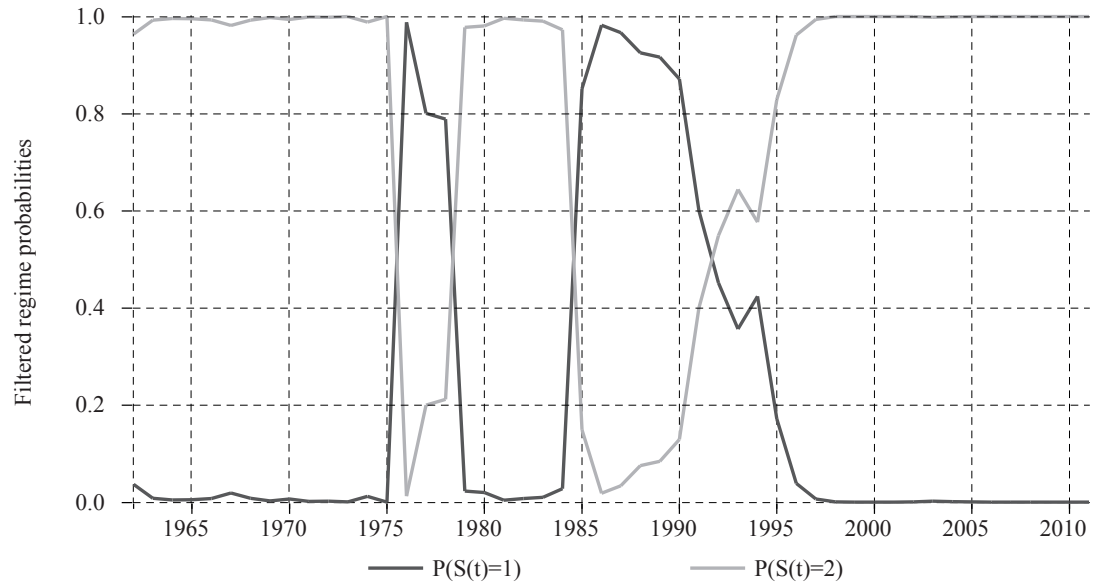

Source: Authors'calculations.

\subsection{LONG-RUN ESTIMATES}

From the Markov Switching results two important structural breaks stand out in around 1975 and 1992. For these two periods, 1961-1975 and 1992-2011, the long-run relationship between the variables was analysed in detail.

First, we performed the Granger Causality Tests, which showed that GDP seems to be helpful in predicting DCPS and vice versa for the entire period studied, and also for the 1992-2011 sub-period. However, in the 1961-1975 sub-period GDP can be seen to be Granger-caused by DCPS, although the opposite does not occur. The results are shown in Table 2 .

TABLE 2

Granger causality tests

\begin{tabular}{|c|c|c|c|}
\hline & 1961-2011 & 1961-1975 & 1992-2011 \\
\hline $\begin{array}{l}\text { GDP does not granger cause } \\
\text { DCPS }\end{array}$ & $\begin{array}{c}0.001 \\
(9.178)\end{array}$ & $\begin{array}{c}0.010 \\
(8.764)\end{array}$ & $\begin{array}{c}0.022 \\
(5.193)\end{array}$ \\
\hline $\begin{array}{c}\text { DCPS does not granger cause } \\
\text { GDP }\end{array}$ & $\begin{array}{c}0.000 \\
(9.871)\end{array}$ & $\begin{array}{c}0.279 \\
(1.504)\end{array}$ & $\begin{array}{c}0.008 \\
(7.144)\end{array}$ \\
\hline
\end{tabular}

Source: Authors' calculations. Tests conducted with 2 lags. The F-statistics are in parenthesis.

When considering the entire period, both the OLS and DOLS estimates show that GDP explains DCPS, and vice versa (see Table 3). However, when analysing the two sub-periods closely, the results are different. In the first sub-period (19611975), both variables are non-stationary and co-integrated, which means that they have to be analysed in a Vector error correction (VEC) model, which is provided by the following form, 
$\triangle D C P S_{t}=\beta_{D C P S, 0}+\beta_{D C P S, G D P,} \Delta G D P_{t-1}+\beta_{D C P S, D C P S, 2} \Delta D C P S_{t-1}+\lambda_{D C P S}\left(G D P_{t-1}-\alpha_{0}-\alpha 1 D C P S_{t-1}\right)+v_{t}^{D C P S}$

where $\triangle G D P$ and $\triangle D C P S$ are GDP and DCPS in first difference, respectively, $\lambda_{G D P}$ and $\lambda_{D C P S}$ are the error-correction coefficients, $v_{t}^{G D P}$, and $v_{t}^{D C P S}$ are the error terms. The expressions in parenthesis are the co-integrating vector between the variables. Please note that the results for OLS and DOLS are presented in Table 3, while the VEC and VEC-Error correction estimations are presented in the following Tables 4 and 5, respectively.

The results from Equation (6) show the existence of short-run causality originating from DCPS to GDP, but the results from Equation (7) do not show the existence of short-run causality originating from GDP to DCPS. This may be explained by the fact that throughout this period, DCPS growth demonstrated erratic behaviour that did not match the growth of GDP. It is clear that DCPS grew significantly, particularly in 1969,1973 , and 1975, whereas GDP did not. In fact, for instance, in 1975 , DCPS grew by $36 \%$, whereas GDP only grew by $1 \%$.

Another detail in Equation (7) is that $\lambda_{D C P S}$ is negative and statistically significant, which means that there is a long-run causality from GDP to DCPS, i.e., GDP causes DCPS in the long-run. In short, GDP causes DCPS in the long-run, but not in the short-run (see Table 4 and 5). The sub-period between 1992 and 2011 also reveals interesting results. Even though the OLS method shows that GDP and DCPS explain each other, the DOLS approach does not show that GDP explains DCPS. Since DOLS is considered to be a more robust and improved method, this final result should be taken into account, because it may be capturing some effects that OLS is not.

It is important to notice that the Granger causality test results seem to contradict the OLS and DOLS results. In the first sub-period, GDP does not Granger-cause DCPS and the VEC model actually does not show short-run causality originating from GDP to DCPS. This may be somewhat explained by the backwardness of the Portuguese economy. In fact, those who had access to credit during the period before the democratic revolution were only a small proportion of the population - the owners of capital. Furthermore, and given the fragile market structure of the Portuguese economy (which was characterised by a lower degree in market competition) and the flow of goods from the metropolis to the colonies, credit requirements tended to grow at a lower rate than the Portuguese economy itself. However, during the second sub-period when GDP and DCPS seem to be helpful in predicting each other, DOLS shows that GDP does not explain DCPS. As mentioned previously, the aim of using the Granger causality test was only to give to provide an idea of the ability of variables to predict each other. Despite this possible contradiction, it is important to consider the limitations of econometric 
analysis, as it is impossible to capture all the effects of all of the variables. A completely correct and flawless analysis is simply impossible to achieve.

TABLE 3

Long-run estimates of Portuguese GDP and DCPS

\begin{tabular}{|c|c|c|c|c|c|}
\hline & OLS & DOLS & & OLS & DOLS \\
\hline & & & 1961-2011 & & \\
\hline \multirow[t]{2}{*}{ DCPS } & $\begin{array}{c}0.000 \\
(4.279)\end{array}$ & $\begin{array}{c}0.000 \\
(12.096)\end{array}$ & GDP & $\begin{array}{c}0.000 \\
(4.279)\end{array}$ & $\begin{array}{r}0.000 \\
(4.338) \\
\end{array}$ \\
\hline & & & 1992-2011 & & \\
\hline DCPS & $\begin{array}{c}0.008 \\
(3.178)\end{array}$ & $\begin{array}{c}0.013 \\
(-2.973)\end{array}$ & GDP & $\begin{array}{c}0.008 \\
(3.178)\end{array}$ & $\begin{array}{r}0.640 \\
(-0.481) \\
\end{array}$ \\
\hline
\end{tabular}

Note: 46 observations for the 1961-2011 and 20 observations for the 1992-2011 period.

Source: Authors' calculations. T-statistics are in parenthesis.

\section{TABLE 4}

Vector error correction (VEC) model estimations, 1961-1975

\begin{tabular}{|c|c|c|}
\hline & GDP & DCPS \\
\hline DCPS & $\begin{array}{c}0.015 \\
(2.995)\end{array}$ & \\
\hline GDP & & $\begin{array}{c}0.582 \\
(-0.570)\end{array}$ \\
\hline
\end{tabular}

Note: 13 observations.

Source: Authors'calculations. T-statistics are in parenthesis.

\section{TABLE 5}

VEC Model: Error-correction coefficients, 1961-1975

\begin{tabular}{ccc} 
& GDP & DCPS \\
\hline$\lambda_{G D P}$ & -0.159 & \\
\hline$\lambda_{D C P S}$ & $(-0.880)$ & -72.566 \\
& $(-4.826)$ \\
\hline
\end{tabular}

Note: 13 observations.

Source: Authors'calculations. T-statistics are in parenthesis.

\section{DISCUSSION AND CONCLUSIONS}

Two main conclusions immediately become apparent from an analysis of the results. The first is that, for the case of Portugal, just as for the case of Ireland, the BCBS approach does not appear to be the most suitable one to adopt. Portugal clearly has two outstandingly different periods (1961-1975 and 1992-2011) which must be taken into account separately. Even though the results considering the entire period seem well-behaved, they disguise the astonishing evolution that this ratio has been experiencing. 
As explained previously, the BCBS approach apparently only works for economies which did not experience a rapid build-up of credit, and our results seem to corroborate this hypothesis. The DCPS-to-GDP ratio can be an indicator of financial instability, yet the approach to analyse this ratio needs to be taken into account carefully in order to produce the best results. As Portugal is a small and open economy, which experienced a sharp growth in credit to households, the country should definitely pay attention to the DCPS-to-GDP ratio as a way of tracking the evolution of indebtedness of households and Portugal's own financial stability.

The second conclusion is that the DOLS results for the second sub-period showing that GDP does not explain DCPS could well suggest a break of the link between deposits and credit. Traditionally, banks grant credit to investors and households according to the level of deposits made by savers and it is this link that has always kept the banking system sound and stable. However, Figure 3 shows the existence of some sub-periods where the growth rate of DCPS was significantly higher than the growth rate of GDP. Assuming that savings are related to a country's economic performance, and also taking into account the fact that Portugal's GDP did not grew significantly over the past two decades, it appears that credit growth was not accompanied by a growth in savings. Indeed, Banco de Portugal (2004) stated that "the strong growth in credit granted by the banking system since the mid-1990s has not been matched by similar developments in resources from customers. In fact, deposits with the Portuguese banking system recorded relatively moderate growth rates over the past few years".

From approximately the 1990 s, the traditional banking conduct was not manifested in the Portuguese banking sector. Due to the lack of domestic resources and a strong growth in credit fuelled by household demand for housing, banks were obliged to resort to alternative forms to finance credit, such as the international financial markets. Banks realised that there was no longer an obligation to grant only credit based on the level of deposits, since they had access to an almost limitless pool of funds at a low interest rate which enabled them to do business differently. For Banco de Portugal (2004) warns - "recourse to market financing is relatively more important for the larger Portuguese domestic groups than for most banks in other European countries". Moreover, Banco de Portugal (2005) states that the increasing share of Portuguese banks' borrowing from international financial markets potentially increases their vulnerability to changes in the sentiment of these markets".

From approximately the time of the April $25^{\text {th }}$ Revolution up until 1977 , the creditto-deposits ratio increased considerably, attaining a level of $121 \%$. Considering the social and political situation at the time, this increase is to be expected, since Portugal received thousands of Portuguese returning from the former colonies after the end of the regime, and this phenomenon was one of the causes of the first IMF intervention in the country. As mentioned earlier, due to the IMF interventions in 1978 and 1983 which established quantitative limits for credit, the 
credit-to-deposits ratio decreased from 1977 onwards and throughout the 1980 decade, reaching 64\% in 1989 - which represents the minimum value recorded in the study's sample. From the 1990s onwards, the ratio increased dramatically, attaining its maximum of $170 \%$ in 2007 . The financial crisis led to a considerable decline in the credit-to-deposits ratio from 2007 to 2010, not only because the crisis caused financial instability, but also, more importantly, because it brought about risk awareness, which made credit standards stricter. Investors were no longer afflicted by myopia and interest rates increased tremendously, as illustrated in Figure 2.

It is also worth mentioning how the current account balance accompanies the evolution presented in Figures 5 and 6. For from around 1996 to 2008, the current account balance decreased significantly, attaining a level of $-12.6 \%$ of GDP in 2008, which means that throughout this period the Portuguese economy was being financed by external savings, i.e., Portugal was living beyond its means. Consequently, the increase in credit without a proper basis contributed to the degradation of the current account balance - which is one of the causes of the current European crisis that is negatively affecting the Portuguese economy.

In conclusion, our paper analyses the reasons for the indebtedness of Portuguese households, which is a topic that has probably not being receiving the attention that it justly deserves, considering its implications for the economy. Since the 2008 financial crisis, there has been a growing concern for the authorities to be provided with the so-called "early warning indicators", in order to be able to take prudent actions when facing financial distress. The BCBS suggests using the HPFilter to determine the Private Sector credit-to-GDP gap i.e., the difference between the credit-to-GDP ratio and its own long-term trend and also recommends this ratio as a common starting point for the authorities to determine whether there is an excessive credit growth, or not. This approach is not criticismproof, and some authors have shown that it is not the most appropriate one to apply for countries which have experienced a rapid build-up of credit. Kelly, McQuinn and Stuart (2011) reached the same conclusion for the case of Ireland, has a small and open economy, similar to that of Portugal.

Using the World Development Indicators data for the DCPS-to-GDP ratio from 1961 to 2011, a two-state Markov Switching model was constructed to explore the structural breaks that the ratio could demonstrate and also the periods where longrun estimates could be made. Two major structural breaks were identified and they show two important sub-periods: 1961 to 1975, and 1992 to 2011. The long-run relationship between DCPS and GDP was analysed for these sub-periods, as well as for the entire period, using OLS and DOLS methods.

There are two main conclusions. The first is that the BCBS approach is not the most suitable one to be applied for the case of Portugal, as it disguises the existence of two distinctly different periods, particularly the second period. The second 
main conclusion is that GDP does not explain DCPS from 1992 to 2011, which probably indicates that the link between deposits and credit was broken during this sub-period. Banks started to obtain financing from international financial markets in order to meet the particularly strong demand of households for housing, which, in fact, was partly encouraged by banks providing attractive mortgages even for households with a more modest income. This irresponsible conduct by the banking sector was not stopped or prevented by Banco de Portugal, which assumed a passive attitude towards the development of this situation, even though it was perfectly aware of it. The dramatic evolution of Portugal's DCPS-to-GDP ratio was a loud "early warning indicator", which was not seriously taken into account by the authorities. This ratio reflected the risky behaviour of Portuguese banks during the 1990s and the beginning of the 2000s, and it fuelled a tremendous build-up of credit which ultimately damaged the country's financial stability.

\section{Figure 5}

Current account balance as \% of GDP, 1980-2011

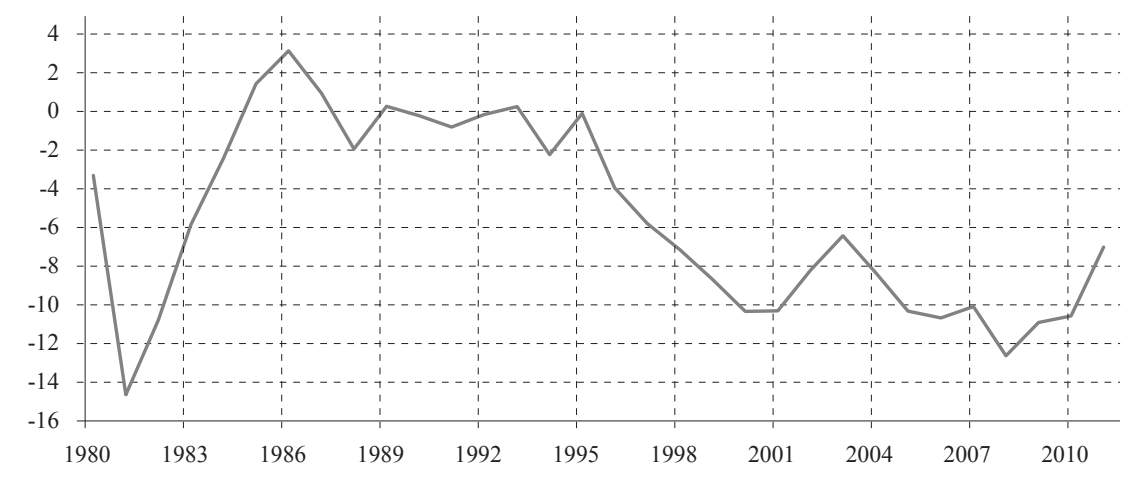

Source: IMF (2013).

The behaviour of the banks throughout the 1990s and the beginning of the 2000s has been seriously and heavily criticised for being irresponsible, since it led to a dramatic growth in credit, based on loose standards. The alternative forms of financing credit other than deposits were justified by the huge demand for houseownership by households. The banks cannot disclaim responsibility for the situation, as they encouraged this demand with attractive mortgages, even for households with modest incomes.

When discussing the banks' responsibility for the levels of indebtedness of households, it is important to point out that during those years of loose credit, the banks' conduct was neither stopped, nor questioned. In its role as the regulator, Banco de Portugal did not find the situation worrisome, and took no actions to prevent the exponential increase of the bank credit-to-banks deposit ratio. 
Throughout the 1990s and the beginning of the 2000s, the regulator's attitude towards the situation was passive and no preventive actions were taken. Nevertheless, Banco de Portugal acknowledged the high levels of indebtedness of households during this period and also the fact that banks made much use of the international financial markets to support credit. One would have expected that in around 2000, Banco de Portugal would have noticed the already significant increase in the credit-to-deposit ratio and that it would have tried to control, or diminish the situation. But on the contrary, it maintained a passive attitude by assuming that there was no problem regarding financial stability, because household debt was based on real assets - houses - and since the institution assumed the inexistence of a housing bubble, these houses would always be an asset which the banks could rely on in case of default. Banco de Portugal (2008) actually states that "financial stability should not be in jeopardy" considering that "credit to individuals being dominated by credit for owner-occupier mortgages helps to explain it". Banco de Portugal also defends itself by saying that there was "no evidence of situations of excessive valuation of property assets in the country".

Banco de Portugal also assumed that there was no considerable risk to financial stability, since the most indebted households were those with low incomes and even though their participation in the debt market was high, their level of borrowing was not significant when compared to the total, as explained above. Banco de Portugal (2008) even stated that "although the near future does not bode well, with an increase in unemployment impacting on the ability of some individuals to honour the debts, there seems to be little likelihood of the situation affecting financial stability in any substantial way." Considering that this was the regulator's stance, the banks basically had free rein to continue with their risky behaviour: there was no demand for them to explain their behaviour and they received no signals from the regulator to control the situation.

Finally, it is important not to forget that other players contributed to this dramatic situation in Portugal. Banks granted credit without a proper basis, however households also got into significantly high levels of debt in comparison to their income. Perhaps most importantly, the regulator adopted a passive attitude towards the situation throughout the most critical years.

\section{Disclosure statement}

No potential conflict of interest was reported by the authors. 
1. Aldasoro, I., Borio, C. and Drehmann, M., 2018. Early warning indicators of banking crises: expanding the family. BIS Quarterly Review, pp. 29-45.

2. Associação Lisbonense de Proprietários, 2011. Retrato da Habitação em Portugal. Lisbon: Associação Lisbonense de Proprietários.

3. Banco de Protugal, 2004. Financial Stability Report 2004. Lisbon: Banco de Portugal.

4. Banco de Portugal, 2005. Financial Stability Report 2005. Lisbon: Banco de Portugal.

5. Banco de Portugal, 2008. Financial Stability Report 2008. Lisbon: Banco de Portugal.

6. Borio, C., McCauley, R. and McGuire, P., 2011. Global credit and domestic credit booms. BIS Quarterly Review, pp. 43-57.

7. Bruno, C. and Shin, S., 2015. Cross-Border Banking and Global Liquidity. The Review of Economic Studies, 82(2), pp. 535-564. https://doi.org/10.1093/ restud/rdu042

8. Castro, G., 2006. Consumption, Disposable Income and Liquidity Constraints. Economic Bulletin, pp. 75-84.

9. Costa, S. 2012. Households' Default Probability: An Analysis Based on the Results of the HFCS. Lisbon: Bank of Portugal.

10. Drehmann, M. [et al.], 2010. Countercyclical Capital Buffers: Exploring Options. BIS Working Paper, No. 317.

11. Drehmann, M., 2013. Total credit as an early warning indicator for systemic banking crises. BIS Quarterly Review, pp. 41-45.

12. Drehmann, M., Borio, C. and Tsatsaronis, K., 2011. Anchoring Countercyclical Capital Buffers: The role of Credit Aggregates. International Journal of Central Banking, 7(4), pp. 189-240.

13. Drehmann, M. and Juselius, M., 2014. Evaluating early warning indicators of banking crises: Satisfying policy requirements. International Journal of Forecasting, 30(3), pp. 759-780. https://doi.org/10.1016/j.ijforecast.2013.10.002

14. Drehmann, M. and Tsatsaronis, K., 2014. The credit-to-GDP gap and countercyclical capital buffers: questions and answers. BIS Quarterly Review, pp. $55-73$.

15. ECB, 2018. European Central Bank - Statistical Data Warehouse. European Central Bank

16. Farinha, L., 2008. Indebtedness of Portuguese Households: Recent Evidence Based on the Household Wealth Survey 2006-2007. Lisbon: Banco de Portugal.

17. Farinha, L. and Costa, S., 2012. Households'indebtedness: a microeconomic analysis based on the results of the households'financial. Lisbon: Bank of Portugal.

18. Farinha, L. and Noorali, S., 2004. Indebtedness and wealth of Portuguese households. Lisbon: Bank of Portugal. 
19. Geršl, A. and Seidler, J., 2011. Excessive Credit Growth as an Indicator of Financial (In)Stability and its Use in Macroprudential Policy. Prague: Czech National Bank.

20. Giese, J. [et al.], 2014. The credit-to-gdp gap and complementary indicators for macroprudential policy: evidence from the UK. International Journal of Finance \& Economics, 19(1), pp. 25-47. https://doi.org/10.1002/ijfe.1489

21. Hansen, N. and Sulla, O., 2013. Credit growth in Latin-America: financial development or credit boom? IMF Working Papers, No. 13/106. https://doi. org/10.5089/9781484390627.001

22. IMF, 2013. World Economic Outlook. Washington: International Monetary Fund.

23. Jordà, Ò., Schularick, M. and Taylor, A., 2011. Financial Crises, Credit Booms, and External Imbalances: 140 Years of Lessons. IMF Economic Review, 59(2), pp. 340-378. https://doi.org/10.1057/imfer.2011.8

24. Kelly, R., McQuinn, K. and Stuart, R., 2011. Exploring the Steady-State Relationship Between Credit and GDP for a Small Open Economy. The Economic and Social Review, 42(4), 455-477.

25. Lopes, J., 1983. A economia portuguesa e os acordos de estabilização económica com o Fundo Monetário Internacional. Economia, 7(3), pp. 555-596.

26. Rubaszek, M. and Serwa, D., 2014. Determinants of credit to households: An approach using the life-cycle model. Economic Systems, 38(4), pp. 572-587. https://doi.org/10.1016/j.ecosys.2014.05.004

27. Shin, H., 2013. Procyclicality and the Search for Early Warning Indicators. IMF Working Papers, No. 2013/258. https://doi.org/10.5089/9781484320839.001

28. Stock, J. and Watson, M., 1993. A simple estimator of cointegrating vectors in higher order integrated systems. Econometrica, 61(4), pp. 783-820. https:// doi.org/10.2307/2951763

29. World Bank, 2013. World Development Indicators. Washington: The World Bank. 